\title{
Pengembangan Bahan Ajar Pendidikan IPS Berbasis Kearifan Lokal Maja Labo Dahu Untuk Pembentukan Karakter Siswa SMP Kabupaten Bima
}

\author{
Safruddin \\ safruddindin033@gmail.com
}

\begin{abstract}
Abstrak. Pengembanga bahan ajar pendidikan IPS dapat mengembangkan pengetahuan, pemahaman dan kemampuan analisis, komunikasi, kerjasama dan bersaing dilingkungan masayarakat yang beragam, baik dikalangan lokal, Nasional, maupun global. Acuan tujuan tersebut berdasarkan tantangan berat yang dihadapi siswa pada masa yang akan datang akibat dinamika hidup masayarakat global yang senantiasa berubah, maka pelajaran bidang studi IPS dirumuskan sebagai pengembangan pengetahuan, pandangan dan kopetensi analisis pada keadaan masyarakat ketika menghadapi situasi kehidupan dalam lingkungan masyarakat. Kehadiran bahan ajar IPS yang berbasis kearifan lokal sangat dibutuhkan khusus bagi siswa. sumber bahan ajar yang bisa digunakan sebagai penunjang pembelajaran khususnya pembelajaran IPS, serta menambah pengetahuan dan wawasan siswa semakin luas. Bahan ajar harus diupayakan sesuai dengan konteks sosial budaya disekeliling siswa dan dapat menumbuhkan kepekaan siswa terhadap keberlangsungan budaya serta kearifan lokal didaerahnya. Generasi muda yang tumbuh pada masa seperti saat ini perlu berkembang lebih dari sekedar generasi dalam sejarah manusia, tatanan yang lebih tinggi, yang meningkat kemungkinan akan terjadi pada latar belakang ras, agama, bahasa, dan budaya yang berbedabeda. Maka generasi sekarang perlu memahami tentang budaya bangsanya. Kearifan lokal yang dimiliki suatu masyarakat dapat membangunan karakter anak yang beridentitas Indonesia. Adapun alternatif yang dapat digunakan peneliti adalah mengembang bahan ajar sesuai dengan teori, karakteristik kebutuhan serta lingkungan tempat tinggal siswa, dan bahan ajar yang dapat menumbuhkan pemahaman siswa, bahan ajar yang dapat menumbuhkan karakter serta pemahaman siswa terhadap kearifan lokal masyarakat Bima.
\end{abstract}

\section{Kata kunci : Pengembangan Pembelajaran IPS Berbasis Kearifan Lokal Maja Labo Dahu}

\section{PENDAHULUAN}

Peran Pendidikan IPS dalam Membentuk Karakter

Pembentukan karakter siswa bukan hanya meniti beratkan pada tugas guru dan pendidikan kewarganegaraan saja, tetapi semua bidang studi memiliki tanggungjawab yang sama. Demikian halnya dengan mata pelajaran IPS, hal itu tercantum dalam Peraturan Mentri Pendidikan Nasional Republik Indonesia Nomor 22 tahun 2006 tentang standar isi untuk pendidikan Dasar dan pendidikan Menegah yang memuat tentang pendidikan IPS sebagai salah satu mata pelajaran yang diberikan mulai dari SD/MI/SDLB Sampai SMP/SMPLB. IPS mengkaji seperangkat peristiwa, fakta, konsep, dan generalisasi yang berkaitan dengan isu sosial. Pada jenjang SMP mata pelajaran IPS memuat materi Geografi, Sejarah, Sosiologi, dan Ekonomi. Melalui pembelajaran IPS, peserta didik dapat diarahkan menjadi warga Negara yang demoktaris, bertanggungjawab dan waraga dunia yang cinta damai.

Mata pelajaran IPS dirancang untuk mengembangkan pengetahuan, pemahaman dan kemampuan analisis terhadap kondisi sosial masyarakat dalam memasuki kehidupan masyarakat yang dinamis. Mata pelajaran IPS disusun secara sistematis, komprehensif, dan terpadu dalam proses pembelajaran menuju 
Terakreditasi Peringkat 5 (No. SK: 85/M/KPT/2020)

kedewasaan dan keberhasilan dalam kehidupan di masyarakat. Dengan pendekatan tersebut diharapkan peserta didik akan memperoleh pemahaman yang lebih luas dan mendalam. Berdasarkan tujuan dan permen tersebut, sudah sangat jelas bahwa pembelajaran IPS merupakan mata pelajaran yang tidak hanya mengembangkan kontekstual saja akan tetapi juga sikap dan keterampilan yang siswa juga butuhkan ketika peserta didik berhadapan langsung dengan kehidupan masyarakat tempat mereka tinggal.

Pendidikan IPS (social studies) menurut Mahood dkk, (1991: 10), The social studies are comprissed oh those aspests of history, geography, and philosophy wich in practice are selected for instruction purposes in schools and collegs" National Council for The Social Studies (NCSS) memberikan definisi yang lebih tegas, seperti yang dikutip Catur (2004), bahwa IPS sebagai " the study of political, economic, cultural, and environment aspects of socienties in the past, presentand future" Noman Sumantri memberikan penjelasan PIPS adalah suatu sinthetic discpline yang berusaha untuk mengorganisasikan dan mengembangkan substansi ilmu-ilmu sosial secara ilmiah dan psikologis untuk tujuan pendidikan. Makna sinthetic discpline, bahwa PIPS bukan sekedar mensistesikan konsep-konsep yang relevan antara ilmu-ilmu pendidikan dan ilmu-ilmu sosial, tatpi juga mengkorelasikan dengan maslaha-maslah kemasyarakatan, kebangsaan, kenegaraan. Secara lebih tegas, bahwa pendidikan IPS memuat tiga sub tujuan yaitu: sebagai pendidikan kewarganegaraan, sebagai ilmu yang konsep dan generalisasinya dalam disiplin ilmu-ilmu sosial, dan sebagai ilmu yang menyerap bahan pendidikan dari kehidupan nyata dalam masyarakat kemudian dikaji secara reflektif.

Tujuan pendidikan secara umum adalah menjadikan peserta didik sebagai warga negara yang baik, dengan berbagai karakter yang berdimensi spiritual, personal, sosial, dan intelektual (Soedarno Wiryohandoyo, (1997). PIPS menurut NCSS mempunyai tujuan informasi dan pengetahuan (kowledge an information), nilai dan tingkah laku (attitude and values), dan tujuan keterampilan (skill): sosial, bekerja dan belajar, kerja kelompok, dan keterampilan intelektual (Jarolimelc, 1986: 5-8). Menurut Awam Mutakin (2006), tujuan dari Ilmu Pengetahuan Sosial (IPS) adalah untuk mengembangkan siswa agar peka terhadap masalah sosial yang terjadi di masyarakat, memiliki sikap mental positif terhadap perbaikan segala ketimpangan yang terjadi, dan terampil mengatasi setiap maslaha yang terjadi sehari-hari baik menimpa dirinya sendiri maupun yang menimpa masyarakat.

Pendidikan IPS memiliki peran strategis dalam membentuk karakter. Pendidikan karakter yang dapat dimaknai sebagai pendidikan nilai, pendidikan moral atau pendidikan budi pekerti sejalan dengan pendapat Darmiyati Zuchdi, (2008: 5). bahwa Pendidikan karakter memiliki arah dan tujuan yang sama dengan tujuan pembelajaran IPS, yakni sama-sama bertujuan agar peserta didik menjadi warga negara yang baik. Pendapat Darmayanti tersebut diperkuat oleh Gross bahwa: values education as social studies to prepare students to be wellfungtioning citizens in democratic society (Hamid Darmadi, 2007: 8).

Al Muchtar , (2008: 339) menegaskan bahwa Pendidikan IPS dan Pendidikan nilai atau pendidikan karakter memiliki kesamaan yang masing-masing bertujuan untuk menjadikan peserta didik sebagai warga negara yang baik. Untuk itu IPS memiliki peran penting dalam pembentukan karakter bangsa, Peserta didik diharapkan peduli terhadap masalah sosial dan lingkungannya, serta memiliki rasa kebangsaan yang tinggi. IPS menjadi fondasi penting bagi pengembangan intelektual, emosional, kultural, dan sosial peserta didik, yaitu mampu menumbuhkan cara berfikir, bersikap, dan berperilaku yang 
Terakreditasi Peringkat 5 (No. SK: 85/M/KPT/2020)

bertanggungjawab selaku individual, warga masyarakat, warga negara, dan warga dunia.

IPS merupakan bagian dari kurikulum sekolah yang tanggungjawab utamanya adalah membentuk karakter peserta didik. Kurikulum sekolah membantu peserta didik dalam mengembangkan pengetahuan, keterampilan, sikap, nilai, dan moral yang diperlukan untuk berpartisipasi dalam kehidupan masyarakat baik di tingkat lokal, nasional maupun global. Hal ini sejalan dengan tujuan Kurikulum IPS tahun 2004, yaitu: mengkaji seperangkat fakta, peristiwa konsep, dan generalisasi yang berkaitan dengan prilaku manusia untuk membangun dirinya, masyarakatnya, bangsanya dan lingkungannya berdasarkan pada pengalaman masa lalu yan yang dapat dimaknai untuk masa kini dan diantisipasi untuk masa yang akan datang. (Mulyasa, 2004: 39).

Proses pembelajaran karakter lebih diarahkan pada aspek pengetahuan, keterampilan dan perilaku James Barth (1990: 254) mengungkapkan bahwa terdapat tiga saspek dalam pembelajaran yang harus dicapai yaitu: a) knowledge, which is a body of fact and principles; b) skill, wich is acquiring an ability throungh experience or training; c) attitude, wich is one's opinion, feeling or mental set as demonstrated by one's actin”. Hal ini sama dengan arah dari pembelajaran IPS, bahwa pembelajaran IPS lebih menekankan aspek pendidikan dari pada transfer konsep agar peserta didik memperoleh pemahaman terhadap jumlah konsep dan mengembangkan serta melatih sikap, nilai, moral, dan keterampilan berdasarkan konsep yang telah dimiliki (Solihatin 2008: 14).

Pembelajaran IPS dibangun sebagai proses transaksi kultural yang harus mengembangkan karakter. Pembelajaran IPS perlu diarahkan sebagai wahana pengembangan pendidikan karakter bangsa, sebagai proses pembangunan kecerdasan, akhlak dan kepribadian peserta didik sesuai dengan tujuan pendidikan nasional. Pembelajaran IPS harus dikembalikan sesuai dengan konseptualnya yang bersifat terpadu yang menekankan pada interdisipliner dan trasdisipliner, dengan pembelajaran yang kontekstual dan transformatif, aktif dan partisipatif dalam perpektif nilai-nilai sosial kemasyarakatan sesuai dengan perkembangan kehidupan masyarakat. Pembelajaran IPS juga harus memfokuskan perannya pada upaya mengembangkan karakter peserta didik untuk menjamin kelangsungan hidup di masyarakat dan lingkungannya. (Sardiman A, 2006: 6).

Terkait dengan pembelajaran IPS, Wayan Lasmawan (2009:2-3) menjelaskan adanya tiga kompetensi dalam pembelajaran IPS, yakni kompetensi personal, kompetensi sosial dan kompetensi intelektual. Sesuai dengan tuntutan zaman dan Dalam mendisain kurikulum pendidikan IPS, termasuk dalam proses pembelajarannya, harus juga berangkat dari hakikat dan karakter peserta didik, bukan berorientasi pada materi semata. Proses pembelajaran IPS diarahkan untuk melahirkan pelaku-pelaku sosial yang berdimensi personal misalnya, berbudi luhur, disiplin, kerja keras, mandiri. dimensi sosiokultural misalnya, cinta tanah air, menghargai dan melestarikan karya budaya sendiri, mengembangkan semangat kebangsaan dan kesetiakawanan sosial, kepedulian terhadap lingkungan. Oleh karena itu, pembelajaran IPS tidak hanya terfokus pada kemampuan intelektual saja, namun kemampuan kecerdasan, akhlak dan kepribadian yang dibutukan oleh peserta didik untuk hidup bermasyarakat.

Pembelajaran IPS dikembangkan sebagai wahana yang efektif untuk menanamkan pemahaman, sikap, dan ketrampilan peserta didik. Setting kelas dalam pembelajaran IPS perlu diciptakan suasana kondusif dan produktif untuk memberikan pengalaman belajar kepada peserta didik dengan melibatkan peserta didik secara proaktif dan interaktif baik dalam proses pembelajaran di kelas maupun di luar kelas sehingga memberi pengalaman belajar yang 
Terakreditasi Peringkat 5 (No. SK: 85/M/KPT/2020)

bermakna (meaningful learning) untuk membentuk dan mengembangkan karakter peserta didik. Dalam konteks pembangunan budaya dan karakter bangsa, mata pelajaran IPS juga memiliki peran yang relevan untuk membina warganegara dalam membangun karakter.

Materi IPS mengembangkan suatu tema dalam pembelajaran. Bahan kajiannya menyangkut peristiwa, seperangkat fakta, konsep dan generalisasi yang berkait dengan isu-isu aktual, gejala dan masalah-masalah atau realitas sosial serta potensi daerah. Isi materi IPS yakni mengenalkan konsep-konsep yang berkaitan dengan kehidupan masyarakat serta mengembangkan pengetahuan, pemahaman, dan kemampuan terhadap kondisi sosial di masyarakat. Hal ini bertujuan agar peserta didik memiliki kemampuan dasar untuk berpikir kritis dan memiliki ketrampilan dalam memecahkan masalah. (Bunyamin Maftuh, 1999: 1).

Guru juga memiliki peranan penting agar pembelajaran IPS menjadi optimal. Menjadi seorang guru IPS harus berpegang pada 5 prinsip pembelajaran yaitu: bermakna (meaningful), terpadu (integrative), menantang (challenging), aktif (active), dan berbasis nilai (value based). Guru harus dapat melatih peserta didik untuk mengembangkan kemampuan dan keterampilan seperti berkomunikasi, beradaptasi, bersinergi, bekerja sama, bahkan berkompetisi sesuai dengan adab dan normanorma yang ada. Selanjutnya, para peserta didik diharapkan menghargai dan merasa bangga terhadap warisan budaya dan peninggalan sejarah bangsa, mengembangkan dan menerapkan nilai-nilai budi pekerti luhur, mencontoh nilai-nilai keteladanan dan kejuangan para pahlawan, para pemuka masyarakat dan pemimpin bangsa, memiliki kebanggaan nasional, ikut mempertahankan jati diri bangsa, dan memiliki kepribadian yang berkarakter. (Winataputra, 1020: 73).

Untuk itu peranan guru dalam pembelajaran IPS sangat penting. Guru harus menguasai hakikat IPS. Guru juga harus dapat menguasai materi dan ketrampilan memetakan $\mathrm{SK} / \mathrm{KD}$. Selain itu, guru harus mampu memilih strategi pembelajaran dan perencanaan pembelajaran IPS secara sistematis. Strategi pembelajaran, media pembelajaran juga perlu diperhatikan dalam pembelajaran IPS. Media pembelajaran IPS bukan sekedar membantu materi kognitif, tetapi sekaligus bertujuan mengembangkan afektif dan psikomotorik peserta didik. Jadi strategi pembelajaran dan model pembelajaran diharapkan mampu menumbuhkan motivasi dan simpati peserta didik untuk mengembangkan ketrampilan sosial. (BSNP, 2006).

Dalam praktek pembelajarannya IPS harus senantiasa memperhatikan konteks yang berkembang pada masyarakat. Pendekatanpendekatan pembelajaran efektif yang di ramu dan disesuaikan dengan perkembangan masyarakat menjadi salah satu instrumen penting untuk diperhatikan agar pembelajaran tetap menarik bagi peserta didik serta senantiasa relevan dengan konteks yang berkembang. Peserta didik dilibatkan dalam setiap proses pembelajaran. Hal ini menjadikan pembelajaran lebih bermakna.

Hakikat dan Peranan IPS di sekolah sebagai kebutuhan masyarakat yang tengah berkembang menuju masyarakat yang sejahtera. Ilmu Pengetahuan Sosial (IPS) sebagai bagian integral dari kurikulum pembelajaran di persekolahan, selayaknya disampaikan secara menarik dan penuh makna dengan memadukan seluruh komponen pembelajaran secara efektif. Hal ini sama pendapat. Martorell, (2008: 14). bahwa arah dari pembelajaran IPS, lebih menekankan aspek pendidikan daripada transfer konsep agar peserta didik memperoleh pemahaman terhadap sejumlah konsep dan mengembangkan serta melatih sikap, nilai, moral, dan ketrampilan berdasarkan konsep yang telah dimiliki.

Materi kajian IPS juga harus didukung pembelajaran yang sesuai dengan karakteristik 
Terakreditasi Peringkat 5 (No. SK: 85/M/KPT/2020)

peserta didik. Pembelajaran IPS adalah suatu sistem pendidikan yang terdiri dari peserta didik, media belajar, fasilitas belajar, dan sumber belajar yang bertujuan untuk membuat peserta didik memahami berbagai integritas dari berbagai Ilmu sosial. Pembeajaran IPS melibatkan peserta didik untuk aktif. Disini peran guru sangat penting untuk memilih media belajar dan mefasilitasi peserta didik, serta memanfaatkan sumber-sumber belajar yang beragam yang ada di dalam lingkungan sekolah maupun diluar sekolah. Pembelajaran IPS mengutamakan peserta didik untuk menempatkan diri pada situasi yang mampu mengkontruksi pemikirannya dan mampu mengekpresikan dirinya secara tepat di lingkungan peserta didik berada.

\section{Pengembangan Bahan Ajar Pendidikan IPS SMP}

Bahan ajar merupakan seperangkat sarana atau alat pembelajaran yang berisikan materi pembelajaran, metode, batasan-batasan, dan cara mengevaluasi yang didesain secara sistematis dan menarik dalam rangka mencapai tujuan yang diharapkan, yaitu mencapai kopetensi dan sub kopetensi dengan segala kompleksitasnya. (Ika Lestari, 2013: 11). Pengertian lain menurut Iskandarwassid dkk, (2011: 171) mengungkapkan bahwa bahan ajar merupakan seperangkat informasi yang harus diserap peserta didik melalui pembelajaran yang menyenangkan. Hal ini menunjukan bahwa penyusunan bahan ajar diharapkan siswa benarbenar merasakan manfaat bahan ajar atau materi itu setelah ia mempelajarinya. Wardana (2010: 29) menambahkan bahwa bahan ajar merupakan suatu media untuk mencapai keinginan atau tujuan yang akan dicapai oleh peserta didik.

Sedangkan menurut Opara dkk, (2011: 66) mengungkapkan bahwa instructional materials are the audio visual material (software/hardware) which can be used as alternative vhannels of communication in the teaching-learning procces. Bahan ajar merupakan sumber belajar berupa visual maupun audiovisual yang dapat digunakan sebagai saluran alternatif pada komunikasi di dalam proses pembelajaran.

Berdasarkan kajian diatas, istilah bahan ajar yang digunakan dalam penelitian ini adalah suatu bahan/materi pelajaran yang disusun secara sistematis yang digunakan guru dan siswa dalam pembelajaran IPS di SMP untuk mencapai tujuan yang dihasilkan. Bahan ajar atau materi pembelajaran (instructional materials) secara garis besar terdiri dari pengetahuan, keterampilan, dan sikap yang harus dipelajari siswa dalam rangka mencapai standar kompetensi yang telah ditentukan.

Sudjana (2010: 11) menyatakan bahwa bahan ajar dapat menyalurkan pesan, dapat merangsang pikiran, perasaan dan kemauan peserta didiksehingga dapat mendorong terciptanya proses belajar pada diri peserta didik. Salah satu fungsi bahan ajar yaitu bisa mewakili guru menyajikan informasi belajar kepada peserta didik.

Masalah penting yang sering dihadapi guru dalam kegiatan pembelajaran adalah memilih atau menentukan materi pembelajaran atau bahan ajar yang tepat dalam rangka membantu siswa mencapai kompetensi. Hal ini disebabkan oleh kenyataan bahwa dalam kurikulum atau silabus, materi bahan ajar hanya dituliskan secara garis besar dalam bentuk "materi pokok". Menjadi tugas guru untuk menjabarkan materi pokok tersebut sehingga menjadi bahan ajar yang lengkap. Selain itu, bagaimana cara memanfaatkan bahan ajar juga merupakan masalah. Pemanfaatan dimaksud adalah bagaimana cara mengajarkannya ditinjau dari pihak guru, dan cara mempelajarinya ditinjau dari pihak murid atau siswa.

Berkenaan dengan pemilihan bahan ajar ini, secara umum masalah dimaksud meliputi cara penentuan jenis materi, kedalaman, ruang lingkup, urutan penyajian, perlakuan (treatment) terhadap materi pembelajaran, dan sebagainya. Masalah lain yang berkenaan dengan bahan ajar 
Terakreditasi Peringkat 5 (No. SK: 85/M/KPT/2020)

adalah memilih sumber di mana bahan ajar itu didapatkan. Ada kecenderungan sumber bahan ajar dititikberatkan pada buku.Padahal banyak sumber bahan ajar selain buku yang dapat digunakan. Bukupun tidak harus satu macam dan tidak harus sering berganti seperti terjadi selama ini. Berbagai buku dapat dipilih sebagai sumber bahan ajar. Termasuk masalah yang sering dihadapi guru berkenaan dengan bahan ajar adalah guru memberikan bahan ajar atau materi pembelajaran terlalu luas atau terlalu sedikit, terlalu mendalam atau terlalu dangkal, urutan penyajian yang tidak tepat, dan jenis materi bahan ajar yang tidak sesuai dengan kompetensi yang ingin dicapai oleh siswa. Berkenaan dengan buku sumber sering terjadi setiap ganti semester atau ganti tahun ganti buku.

Sehubungan dengan itu, perlu disusun rambu-rambu pemilihan dan pemanfaatan bahan ajar untuk membantu guru agar mampu memilih materi pembelajaran atau bahan ajar dan memanfaatkannya dengan tepat. Rambu-rambu dimaksud antara lain berisikan konsep dan prinsip pemilihan materi pembelajaran, penentuan cakupan, urutan, kriteria dan langkah-langkah pemilihan, perlakuan atau pemanfaatan, serta sumber materi pembelajaran.

\section{Fungsi Bahan Ajar}

Secara garis besar, fungsi bahan ajar bagi guru adalah untuk mengarahkan semua aktivitasnya dalam proses belajar mengajar sekaligus merupakan substansi kopetensi yang seharusnya diajarkan kepada siswa. Fungsi bahan ajar bagi siswa untuk menjadi pedoman proses pembelajaran dan merupakan substansi kopetensi yang seharunya dipelajari. Bahan ajar juga berfungsi sebagai alat evaluasi pencapaian hasil pembelajaran. bahan ajar yang baik sekurang-kurangnya mencakup petunjuk belajar, kopetensi yang akan dicapai, isi pelajaran, informasi pendukung, latihan-latihan, petunjuk kerja, evaluasi dan respon terhadap hasil evaluasi. Prastowo (2011:2004).
Karakteristik siswa yang berbeda berbagai latar belakang akan sangat membantu dengan adanya kehadiran bahan ajar, karena dapat dipelajari sesuai dengan kemampuan yang memiliki sekaligus sebagai alat evaluasi penguasaan hasil belajar karena setiap hasil belajar dalam bahan ajar akan selalu dilengkapi dengan sebuah evaluasi guna mengukur penguasaan kopetensi.

Berdasarkan strategi pembelajaran yang digunakan, fungsi bahan ajar dapat dibedakan menjadi tiga macam yaitu fungsi dalam pembelajaran klasikal, pembelajaran individual, dan pembelajaran kelompok. Pratowo, (2011:25). Pertama, fungsi bahan ajar dalam pembelajaran klasikal adalah: sebagai satusatunya informasi serta pengawasan dan pengendalian proses pembelajaran dalam hal ini siswa, bersifat pasif dan belajar sesuai kecepatan siswa dalam belajar dan sebagai bahan pendudkung proses pembelajaran yang berlangsung. Kedua, fungsi bahan ajar dalam pembelajaran individual adalah: sebagai media utama dalam proses pembelajaran dan sebagai alat yang digunakan untuk menyusun dan mengawasi proses peserta didik dalam memperoleh informasi. Ketiga, fungsi bahan ajar dalam pembelajaran kelompok adalah sebagai bahan yang terintegrasi dengan proses belajar kelompok dengan cara memberikan informasi tentang latar belakang materi, informasi tentang peran orang-orang yang terlibat dalam pembelajaran kelompok, serta petunjuk tentang proses pembelajaran kelompok sendiri, dan sebgai bahan pendudkung bahan ajar utama dan apabila dirancang sedemikian rupa, maka dapat meningkatkan motivasi belajar siswa.

\section{Konsep Kearifan Lokal}

Kearifan lokal dilihat dari kamus inggris indonesia terdiri dari 2 kata yaitu kearifan (wisdom) dan lokal (local) berarti setempat dan wisdom berarti sama dengan kebijaksanaan. Dengan kata lain maka local wisdom dapat dipahami sebagai gagasan-gagasan nilai-nilai 
Terakreditasi Peringkat 5 (No. SK: 85/M/KPT/2020)

pandangan-pandangan setempat (local) yang bersifat bijaksana, penuh kearifan bernilai baik, yang tertanam dalam diri masyarakat.

Secara etimologi wisdom dipahami sebagai kemampuan seseorang dalam menggunakan akal pikirannya dalam bertindak atau bersikap sebagai hasil penilaian terhadap sesuatu, objek atau peristiwa yang terjadi. Sebagai sebuah istilah wisdom sering diartikan sebagai kearifan/bijaksana. Lokal secara spesifik menunjuk pada ruang interaksi terbatas dengan sistem nilai yang terbatas pada sebuah lokasi atau daerah tertentu sebagai ruang interaksi yang sudah didesai sedemikian rupa yang didalamnya melibatkan suatu pola hubungan antara manusia dengan manusia atau manusia dengan lingkungan fisiknya.pola interaksi yang sudah terdesain tersebut disebut setting. Sebuah seting kehidupan yang sudah terbentuk secara langsung akan memproduksi nilai-nilai tersebut yang akan menjadi landasan hubungan mereka atau menjadi acuan tingkah laku mereka.

Menurut Sibarani, (2012: 112) menjelaskan bahwa kearifan lokal adalah kebijaksanaan atau pengetahuan asli suatu masyarakat yang berasal dari nilai luhur tradisi budaya untuk mengatur tatanan kehidupan masyarakat. Kearifan lokal juga dapat didefinisikan sebagai nilai budaya lokal yang dapat dimanfaatkan untuk mengatur tatanan kehidupan masyarakat secara arif atau bijaksana. Sehingga mampu memberikan sumbangsih kepada kehidupan masyarakatnya. Jadi dapat dikatakan bahwa kearifan lokal terbentuk sebagai sebuah keunggulan budaya masyarakat setempat berkaitan dengan kondisi yang terdapat pada budaya masyarakat. Kearifan lokal merupakan produk budaya masa lalu yang patut secara terus menerus dijadikan pegangan hidup. Meskipun nilai-nilai yang ada berisat lokal tetapi nilai yang terkandung didalamnya dianggap sangat universal. Pengertian ini memandang kearifan lokal tidak hanya sekedar sebagai acuan tingkah laku seseorang dalam bermasyarakat tetapi lebih jauh, yaitu mampu mendianamisasikan kehidupan masyarakat yang penuh dengan keluhuran budi dan keadaban.

Secara substansial, kearifan lokal itu adalah nilai-nilai yang berlaku dalam suatu masyarakat. Nilai-nilai yang diyakini kebenarannya dan menjadi acuan dalam beringkah laku sehari-hari masyarakat setmpat oleh karena itu sangat tepat jika terdapat pandangan bahwa kearifan lokal merupakan sebuah komponen dalam masyarakat yang sangat menentukan harkat dan martabat manusia dalam komunitasnya. Hal ini menunjukan bahwa kearifan lokal yang didalamnya berisi unsur kecerdasan kreativitas dan pengetahuan lokal para elit dan masyarakatnya amat menentukan dalam proses pembangunan peradaban masyarakatnya.

Masyarakat Indonesia begitu beragam, kearifan lokl dapat kita temui dalam tradisi, nyanyian adat, benda-benda peninggalan masa lalu, petuah, semboyan, dan kitab-kitab kuno yang melekat dalam perilaku individu dalam keshariannya. Kearifan lokal biasanya tercermin dalam pola perilaku dan kebiasaan hidup masyarakat yant telah berlangsung sejak lama.

Proses pembelajaran berbasis kearifan lokal merupakan pembelajaran yang akan menempatkan siswa sebagai pusat pembelajaran (Student Centered) daripada berpusat pada guru (Teacher Centered). Hal ini sesuai dengan konsep bahwa belajar tidak sekedar kegiatan pasif menrima transfer pengetahuan dari guru, melainkan proses aktif mengali, mencari dan menemukan pengalaman baru selama proses pembelajaran sehingga menjadi bermakna. Bagi guru mengajar adalah kegiatan memfasilitasi siswa dalam proses megkonstruksi sendiri pengetahuannya lewat keterlibatanya dalam kehidupan sehari-hari. Sudjana, (2013: 76).

Pembelajaran berbasis kearifan lokal dalam pembelajaran IPS di sekolah dirasa sangatlah tepat. Pembelajaran dilakukan dengan cara mengintegrasi nilai-nilai kearifan lokal 
Terakreditasi Peringkat 5 (No. SK: 85/M/KPT/2020)

kedalam mata pelajaran IPS. Hal ini sesuai dengan tujuan IPS yatu agar siswa mampu mengembangkan gagasan, wawasan, pemahaman dan keterampilan untuk menyelesaikan maslah sosial yang terjadi dikehidupan siswa, sesuai dengan kemampuan gaya belajarnya. Supardan, (2011: 17).

Pembelajaran IPS berbasis kearifan lokal ini dilakukan dengan mengintegrasikan berbagai bentuk kearifan lokal yang ada dilingkungan peserta didik kedalam mata pelajaran IPS. Tujuannya untuk memperkenalkan kearifan lokal didaerah setempat pada siswa melalui mata pelajaran IPS. Dengan demikian diharapkan siswa menyadari akan pentingnya nilai-nilai lokal tersebut dan menginternalisasikan kedalam nilai-niali tersebut kedalam tingkah lakunya sehari-hari melalui proses pembelajaran, baik yang berlangsung didalam maupun diluar kelas. Hal ini sejalan sengan pendapat Yamin (2012: 215). pendidikan yang tepat ialah Ketika ia mampu menjawab persoalan-persoalan yang dihadapi masyarakat setmpat. Oleh sbab itu, sudah saatnya pembelajaran kembali memanfaatkan potensi lokal daerahnya sebagai salah satu muatan pembelajaran yang diajarkan di sekolahsekolah.

\section{Fungsi Kearifan Lokal}

Keberadaan kearifan lokal berfungsi. Sartika (2006: 56) mengatakan bahwa fungsi kearifan lokal adalah berfungsi untuk konservasi dan pelestarian sumber daya alam untuk mengembangkan sumber daya manusia serta berfungsi untuk pengembangan kebudayaan dan ilmu pengetahuan maupun sosial etika dan moral. Terkait dengan pembelajaran kearifan lokal disekolah menurut Sutarno (2008:7) ada empat macam pembelajaran berbasis budaya yaitu: Pertama, belajar tentang budaya berarti menempatkan budaya sebagai bidang ilmu.

Dalam hal ini program studi khusus, tentang budaya dan untuk budaya dalam hal ini budaya tidak terintegrasi dengan ilmu. Kedua, belajar dengan budaya terjadi pada saat budaya diperkenalkan kepada siswa sebagai cara atau metode untuk mempelajari materi pada pokok pembahasan tertentu. Belajar dengan budaya meliputi pemanfaat beragam untuk mewujudkan budaya dalam pembelajaran ini menjadi media pembelajaran dalam proses belajar menjadi penerapan pronsip dalam satu mata pelajaran. Tiga, belajar melalui budaya merupakan strategi memberikan kesempatan kepada siswa untuk menunjukkan pencapaian pemahaman atau makna yang diciptakkanya dalam dalam satu mata pelajaran melalui ragam perwujudan budaya. Empat, merupakan bentuk menjawatahkan budaya itu dalam perilaku nyata sehari-hari kepada siswa. Mislanya anak dibudayakan untuk selalu mencium tangan orang tua sebelum berangkat sekolah, atau selalu bertutu kata dengan lemah lembut saat berkomunikasi dengan kedua ornag tua.

Kearifan lokal Maja Labo Dahu

Maja labo dahu merupakan sebuah tradisi perilaku moral-etik atau nilai adat yang berlaku dalam kehidupan masyarakat Bima. Dengan kata lain, Maja Labo Dahu merupakan prinsip nilai kehidupan seseorang atau sebuah pandangan yang mengajarkan untuk merasa takut dan malu ketika tidak melakukan kebaikan, kebajikan, kebenaran berdasarkan perintah Agama serta menegakkan amal ma'ruf nahi mungkar (QS. Ali Imran, ayat 114).

Kearifan lokal Maja Labo Dahu memiliki dua susku kata yang berbeda Maja Labo Dahu yang berarti "malu dan takut" secara leksikal "Maja" berarti malu, kemudian "Dahu" yang berarti takut. Dengan demikian Maja labo Dahu memiliki arti Malu dan Takut. Sedangkan secara filosofis "Maja Labo Dahu" bermakna: Pertama, Maja dikonsepsikan sebagai sebuah sikap moral manusia untuk merasa malu terhadap tindakan yang menyimpang, atau melanggar hukum baik hukum Agama, hukum Negara dan etika sosial-budaya yang mencerminkan kearifan lokal sebuah komunitas masyarakat. Sejalan dengan pendapat Siti Mariam, (2004 : 105 ), bahwa: Ajaran "Maja" 


\section{Terakreditasi Peringkat 5 (No. SK: 85/M/KPT/2020)}

memberikan nilai moral dan etika pada manusia tentang perbuatan yang salah begitu sangat memalukan, dan hal yang memalukan merupakan "aib besar" bagi orang Bima yang tidak bisa dibayar apa lagi dikembalikan sebagaimana mestinya kecuali dengan menebusnya dengan cara meninggalkan hal-hal yang memalukan tersebut atau menjauhi setiap hal yang memalukan. Dipertegas dengan pendapat Sharsi, (2010 : 37), bahwa: Rasa malu merupakan esensi dasar moralitas manusia, rasa malu diartikan sebagai esensi yang menjadikan manusia sebagai manusia dan membedakannya dengan mahkluk yang tidak meliki kehormatan (binatang) dan memiliki kehormatan (manusia yang berbudaya). Jika rasa malu hilang dalam diri seseorang maka hilang pulalah esensi dasar kebaikan dalam dirinya yaitu moral dan etika (ahklak), selanjutnya jika keduanya hilang maka hilang pula kemanusiaannya, jika ini sudah terjadi maka sesungguhnya orang demikian bukanlah manusia tetapi mahluk yang lebih rendah dari binatang. Spesies tersebut dalam hidupnya bukan saja keburukan dan kejahatan dianggap kebaikan tetapi keberadaannya menimbulkan bencana bagi yang lain dan penyakit sosial (sociaty of phatolgy) pada lingkungan. Seseorang yang tidak punya merupakan manusia yang kehilangan sensitifitas sebab hati nuraninya telah mati,akalnya mati, mata dan telinganya telah buta sehingga tidak lagi bisa membedakan kebenaran dan kebatilan, kebaikan dan kejahatan.

Kedua, Dahu; merupakan sebuah perilaku moral-etik lahir dari dalam diri seseorang yang merasa berat untuk tidak melakukan perbuatan-perbuatan baik dan benar yang dianjurkan Agama maupun aturan-aturan hukum positif dan niai-nilai adat yang berlaku dalam kehidupan masyarakat. Dengan kata lain, Dahu merupakan prinsip nilai kehidupan seseorang yang mengajarkan untuk merasa takut ketika tidak melakukan kebaikan, kebajikan, kebenaran berdasarkan perintah Allah. Serta perintah Undang-undang yang berlaku.
Kedua nilai budaya (cultural value) di atas merupakan sebuah pandangan dunia (world view) masyarakat Bima yang bersumber dari kearifan lokal (local genius) yang diwarisi sejak zaman dahulu. Secara eksplisit jika kita melakukan studi konparasi dengan Islam atau Islam approaches tentang "Maja labo Dahu", maka akan banyak ayat-ayat maupun hadist yang menerangkan keterkaitan dengan hal terebut. Seperti yang Allah jelaskan dalam QS. Al-Baqarah ayat 74 tentang orang-orang yang tidak punya "malu" dan "takut" ini dikarenakan hatinya menjadi keras seperti batu bahkan lebih keras lagi dari itu yang menyebabkan cahaya hidayah Tuhan itu semakin menjauh dan gelap. Oleh sebab itu budaya maja labo dahu sangat kompatibel dengan Islam bahkan niai budaya maja dan dahu adalah ajaran Islam, dengan kata lain bukan sekedar ajaran budaya tetapi perintah Tuhan. "Maja labo Dahu" bukan sekedar omong kosong budaya belaka atau dogma tradisi nihil dari dongeng-dongeng nenek moyang yang diceritakan kepada anaknanaknya setiap berkumpul. Tetapi Maja labo Dahu merupakan ajaran moral etik yang berakar pada falsafah Agama, kearifan budaya yang hidup dan falsafah kehidupan yang baik dan benar yang tentu harus diterapkan pada setiap dimensi kehidupan yang kita jalani setiap harinya, tidak hanya berhubungan dengan sesama manusia, hubungan dengan Tuhan, hubungan dengan lingkungan (alam) tetapi juga mengajarkan tentang bagaimana berhubungan baik dengan diri sendiri, mengatur dan membimbing diri sendiri.

Menurut Ahmad H. (2006 : 132). Ada 4 aspek yang dirangkum oleh Maja Labo Dahu dalam proses sosialisasi masyarakat Bima. Antara lain : Pertama, manusia mengadakan interaksi dengan dirinya. Kedua, wujud kehidupan manusia dengan manusia lainnya. Ketiga, wujud kehidupan manusia dengan lingkungannya. Keempat, wujud kehidupan manusia dengan Tuhannya. Keempat aspek tersebut saling mempengaruhinya dan saling 
Terakreditasi Peringkat 5 (No. SK: 85/M/KPT/2020)

membutuhkan. Memanfaatkan potensi diri bukan hanya dengan kemampuan dan kesanggupan, tetapi bagaimana seseorang menempatkan dan memandu kata hati dalam porsi yang wajar.Siapa yang mampu memahami dirinya secara intens, berarti dia mampu menguasai dirinya. Apabila manusia malu pada dirinya dan takut pada Tuhannya, berarti prinsip hidup yang dia miliki tak tergoyahkan. Hal tersebut sejalan dengan pendapat, Henry Chambert Loir (1982 : 69) menyatakan bahwa: Malu bukan terbatas pada sisi kehidupan tertentu, tetapi menyangkut masalah martabat, harga diri dan kehormatan yang terangkum, untuk dipelihara, diwujudkan dan dipertahankan dalam kehidupan sehari-hari.Setiap orang memiliki kewajiban untuk menjaga, menegakkan malu, agar tidak tercemar di mata orang lain, umumnya masyarakat.

Demikian halnya dengan kearifan lokal maja labo dahu atau malu dan takut, filosofi orang Bima tidak terbatas pada orang dan golongan tertentu, tapi semua golongan: kaya, miskin, tua, muda, pejabat, maupun rakyat biasa. Indikasinya adalah segala aktifitas orang bima tetap tercermin pada prinsip tersebut, di sisi lain manusia dalam berbuat dan bertindak selalu mengevaluasi diri. Sebab, Maja Labo Dahu (malu dan takut) bukan hanya patokan tetapi cermin. Kearifan lokal maja labo dahu sebagai cermin pada diri sesungguhnya menggugah rasa dan pikiran untuk berbuat dan bertindak secara jujur, hati-hati, teliti dan tidak gegabah. Sedangkan secara eksternal, bersikap terbuka, menghargai orang lain, ramah, memiliki kasih sayang dan saling mencintai kepada sesama. Tidak ada hidup yang tidak saling membutuhkan, persoalannya terletak pada kepentingan dan takaran. Secara sosiologis orang yang keluar dari takaran dan kepentingan, berada dalam ruang gerak yang tak terkendali. Filosofi orang Bima kekayaan yang paling berharga adalah "taho ade" (kebaikan hati). Cirinya adalah, semua manusia dipandang sama. Menghargai seseorang bukan karena jabatan, kedudukan, pangkat dan harta, tapi karena dasar cinta.

\section{Pendidikan Berbasis Kearifan Lokal Sebagai Pendekatan dalam Pembelajaran IPS}

Pendidikan berbasis kearifan lokal tidak sekedar merevisi materi pembelajaran tetapi melakukan reformasi dalam sistem pembelajaran itu sendiri. Menurut Rahardiansyah S. (2013: 245) menyatakan bahwa ada beberapa pendekatan dalam proses pendidikan berbasis kearifan lokal yaitu:

Pertama, tidak lagi terbatas pada menyamakan pandangan pendidikan (education) dengan persekolahan (schooling) atau pendidikan berbasis kearifan lokal dengan program-program sekolah formal. Pandangan lebih luas mengenai pendidikan sebagai transmisi kebudayaan membebaskan pendidikan dari asumsi bahwa tanggungjawab primer mengembangkan kopetensi kebudayaan dikalanagan anak didik semata-mata berada ditangan mereka justru semakin banyak pihak yang bertanggungjawab karena programprogram sekolah seharusnya terkait dengan pembelajaran informal di luar sekolah.

Kedua, menghindari pandangan yang menyamakan kebudayaan dengan kelompok etnik adalah sama. Artinya, tidak perlu lagi mengasosiasikan kebudayaan semata-mata dengan kolompok-kelompok etnis sebagaimana yang terjadi selama ini. Secara tradisional, para pendidik mengasosiasikan kebudayaan hanya dengan kelompok-kelompok sosial yang relative self sufficient, ketimbang dengan sejumlah orang yang secara terus menerus dan berulang-ulang terlibat satu sama lain dalam satu atau lebih kegiatan. Dalam konteks pendidikan berbasis kearifan lokal, pendekatan ini diharapkan dapat mengilhami para penyusun program pendidikan berbasis kearifan lokal untuk melenyapkan kecendrungan memandang peserta didik secara streotip menurut identitas etnik mereka dan akan meningkatkan eksplorasi pemahaman yang lebih besar mengenai 
Terakreditasi Peringkat 5 (No. SK: 85/M/KPT/2020)

kesamaan dan perbedaan dikalangan peserta didik dari berbagai kelompok etnik.

Ketiga, karena pengembangan kopetensi dalam suatu kebudayaan baru biasanya membutuhkan iteraksi inisiatif dengan orangorang yang sudah memiliki kopetensi, bahkan dapat dilihat jelas bahwa upaya-upaya untuk mendukung sekolah-sekolah yang terpisah secara etnik adalah antithesis terhadap tujuan pendidikan berbasis kearifan lokal. Mempertahankan dan memperluas solidaritas kelompok adalah menghambat sosialisasi kedalam budaya baru. Pendidikan bagi pluralism budaya dan pendidikan berbasis kearifan lokal tidak dapat disamakan secara logis.

Keempat, pendidikan kearifan lokal meningkatkan kopetensi dalam beberapa kebudayaan. Kebudayaan mana yang diadopsi ditentukan oleh situasi. Kelima, kemungkinan bahwa pendidikan (baik dalam maupun luar sekolah) meningkatkan kesadaran tentang kopetensi dalam beberapa kebudayaan. Kesadaran seperti ini kemudian akan menjauhkan kita dari konsep dwi budaya atau dikotomi antara pribumu. Dikotomi semacam ini bersifat membatasi individu untuk sepenuhnya mengekspresikan diversitas kebudayaan. Pendekatan ini meningkatkan kesadaran akan multikulturalisme sebagai pengalaman normal manusia. Kesadaran ini mengandung makna bahwa pendidikan multicultural berpotensi untuk menghindari dikotomi dan mengembangkan apresiasi yang lebih baik melalui kopetensi yang ada pada diri anak didik.

Dalam konteks keindonesiaan dan kebinekaan, kelima pendekatan tersebut haruslah diselaraskan dengan kondisi masyarakat Indonesia. Pendapat ini juga di kemukakan oleh Zakiah Darajat, (2015: 247) yang menyatakan bahwa: masyarakat secara sederhana diartikan sebagai kumpulan individu dan kelompok yang diikat oleh kesatuan Negara, kebudayaan dan agama. Jadi dapat dipahami inti masyarakat adalah kumpulan besar individu dapat memenuhi kebutuhan mereka dan menyerap watak social. Dari sisi lain, apabila kehidupan didalam masyarakat berarti interaksi antar individu dan lingkungan sosialnya. Maka menjadi pembentukan individu tersebut adalah pendidikan dengan istilah lain masyarakat pendidik.

Untuk itu, setiap anggota masyarakat memiliki peranan dan tanggungjawab moral terhadap pelaksanaan proses pendidikan. Hal ini disebabkan adanya hubungan timbal balik antara masyarakat dan pendidikan. Dalam upaya memperdayakan masyarakat dalam dunia pendidikan merupakan satu hal penting untuk kemajuan pendidikan.

Dalam penelitian ini pembelajaran IPS berbasis kearifan lokal Dalam praktek pembelajarannya harus senantiasa memperhatikan konteks yang berkembang pada masyarakat.

Pendekatan-pendekatan pembelajaran efektif yang di ramu dan disesuaikan dengan perkembangan masyarakat menjadi salah satu instrumen penting untuk diperhatikan agar pembelajaran tetap menarik bagi peserta didik serta senantiasa relevan dengan konteks yang berkembang. Peserta didik dilibatkan dalam setiap proses pembelajaran. Hal ini menjadikan pembelajaran lebih bermakna.

\section{DAFTAR PUSTAKA}

Adisusilo Sutarjo. (2013). Pembelajaran Nilai Karakter; Konstruktivisme dan VCT Sebagai Inovasi Pendekatan Pembelajaran Afektif. Jakarta: PT Raja Grafindo Persada.

Almuchtar, S. (2008). Inovasi Dan Trasformasi Pembelajaran Pendidikan IPS. Bandung: Gelar Pustaka Mandiri.

Awam Mutakin (2006). Individu, Mayarakat Dan Perubahan Social. Bandung; FPIPS-UPI

Barnawi \& M. Arifin.( 2012), Strategi dan Kebijakan Pembelajaran Pendidikan Karakter. Yogyakarta: AR-Ruzz Media 
Terakreditasi Peringkat 5 (No. SK: 85/M/KPT/2020)

Bidell dan Fischer, (2005). "Belajar dan Pembelajaran. Jakarta: Rineka Cipta.

Danim, Sudarwan. (2011), Perkembangan Peserta Didik. Bnadung: Alfabet.

Darmiyati Zuchdi. (2008). Humanisasi Pendidikan: menemukan kembali pendidikan yang manusiawi.

Depdiknas. 2006. Pedoman Memilih dan Menyusun Bahan Ajar. Jakarta: Depdiknas.

Hamid Darmadi. (2007). Konsep Dasar Pendidikan Moral. Bandung: Alfabeta. Kirsten Lewis. (1996). Character Education Manifesto. Boston: Boston University.

Henry Chambert Loir,(1982) Arsip-Arsip Dokumen Penting Tentang Muhamad Sallahudin Dana Mbojo.Gramadia : Jakarta

Henri Chamber (2004). Kerajaan Bima Dalam Sastra Dan Sejarah. Gramadia : Jakarta

Ika Lestari. 2013. Pengembangan Bahan Ajar Berbasis Kompetensi. Padang: Akademia Permata.

Gunawan, Heri. 2012. Pendidikan Karakter, Konsep dan Implementasi. Bandung: Alfabeta.

Kurniawan Syamsul. (2017). Pendidikan Karakter di Sekolah: Revitalisasi Peran Sekolah Dalam Menyiapkan Generasi Bangsa Yang Berkarakter. Yogyakarta: Samudra Biru.

Lestari,I. (2013) Pengembangan Bahan Ajar Berbasis Kopetensi. Jogjakarta ArRuzz- Media

Numan Sumatri. (2001).Pembaharuan Pendidikan IPS. Bandung: Rosda Karya.

Rahardiansah T. dkk.(2013) Transformasi Niali Kearifan Lokal Dalam Pendidikan Bangsa. Jakarta : Universitas Trisakti.

Sapriya. (2009). Pendidikan IPS. Bandung: PT Remaja Rosdakarya. 